\title{
Human Resource Management and Leadership: Lessons from Lee Kuan Yew
}

\author{
S M Saleh Reza, S M Sazid Raihan, Md. Rabiul Islam Rabi
}

\begin{abstract}
Singapore, during its separation from Malaysia in 1965, was a melting pot of different races. Not every leader can manage its human resources to its best use. Lee Kuan Yew, the founding father of Singapore, is famous for his leadership dexterities in navigating a third world country to a first world one. Lee's success can be attributed to his astute decisive role in governance issues. Lee kept his government small, paid them best and curbed corruption. His philosophy in governance issues has been proved pragmatic in shaping the long term future of the state. While curbing corruption, he upheld rule of law, improved social service and set Singapore as an example to the world. Lee espoused the idea to produce an elite with intellectual and moral upbringing to lead Singapore's nation building mission. In the quest of building a prosperous Singapore, Lee placed a high premium on quality leadership. This paper explores the lessons one can draw in the arena of Human Resource Management and Leadership from Lee Kuan Yew as a statesman.
\end{abstract}

Keywords - Human Resource Management, Leadership, Governance, Meritocracy, Talent Management, Competitive Compensation.

\section{Introduction}

"There is no reason why third world leaders cannot succeed...if they can maintain social order, educate their people, maintain peace with their neighbors, and gain the confidence of investors by upholding the rule of law."

- Lee Kuan Yew, Singapore's Founding Father

If one asks a person in Singapore to direct you to a monument of Lee Kuan Yew, the founding father of Singapore, the reply you are going to get is perhaps "Look around you". Lee Kuan Yew, also known for his initials LKY, set examples for world leaders in leading a state. Mr. Lee, with his delicate statecraft, leaded Singapore from a British Colonial Outpost to prosperous metropolis. After the separation from Malaysia in 1965, Singapore had a racial mix, booming unemployment and economic instability.

S M Saleh Reza

Faculty, Daffodil International University

Dhaka, Bangladesh

S M Sazid Raihan

School of Business, North South University

Dhaka, Bangladesh

Md. Rabiul Islam Rabi

Research Associate, Lead to Live Foundation

Dhaka, Bangladesh
Devoid of any natural resources, Lee focused on capitalizing on the only resource the country had access to- its human resource, to shape the long term future of the country. Instead of building public squares, statues, monuments on mountaintops after the national figure, Lee Kuan Yew founded a school of public policy to promote knowledge. The article will engage in exploring philosophy of Lee Kuan Yew on leadership, governance and meritocracy. Under the leadership of Lee, governance helped Singapore transcend its neighbors. In this article, we examine the philosophy of Lee Kuan Yew to draw lessons for Human resource management and leadership.

\section{Leadership Philosophy}

Singapore, a country with no natural resources, pedaled to a first world country under the leadership of Lee Kuan Yew. According to World Bank Statistics, today, Singapore is an ultra-modern metropolis with higher per capita GDP than the United States.

Lee's conception of leadership and governance set him apart from other leaders. For the sake of prosperity, he curbed democratic freedom, however, at the same time, developed and nurtured leadership skills among the individuals through implementing a wide array of modern human resource and talent management practices and philosophies. While west emphasizes on a democratic philosophy, Lee devised his own strategy as a statesman to take Singapore forward.

There are many attributes which contributed to Lee's success a leader. Not every leader can manage its human resources to its best use. Singapore, during its separation from Malaysia in 1965, was a melting pot of different races. Lee's success can be attributed to his astute decisive role in governance issues. Lee kept his government small, paid them best and curbed corruption. In 1966, Lee addressed the school principals with the following words implying the "thin crust" of his government:

"This government at the moment - the whole of this administration - is running on I would say the ability and drive and dedication - not on the basis of what they get in salaries - of about 150 people. You remove these 150 people, if you can identify the 150; whoever wants to destroy this society, identifies these 150 people and kills them, the push will be gone. This is a very thin crust of leadership" [1].

"Performance" was the basis of Lee's concept of leadership. Lee undertook drastic reforms and set high standards to lead the country with a homegrown group of leader. The "thin 
crust" of charismatic leaders was increased to 300 by 1971 . In Lee's words:

"If all 300 were to crash in the one Jumbo jet, then Singapore will disintegrate. That shows how small the base is for our leadership in politics economics and security. We have to, and we will, enlarge this base, enlarging the number of key digits" [2].

Getting the pieces of puzzle in right place was not easy for a bereft of natural resources like Singapore. Lee had a longterm vision of economic growth and focused on export-led growth to forge the country's economic foundation. Maintaining a stable currency, encouraging savings and investment, moving from labor intensive economy to skill intensive economy were all pieces of the puzzle to get the economy of Singapore into the pedestal of First World Country. Considerable infrastructure investment was crucial to nation's economic growth as suggested in the book "Lee Kuan Yew: The Grand Master's Insights on China, the United States, and the World".

The leadership traits of Lee encompasses governance and his meritocratic orientation. The paper will now explore the governance and meritocratic philosophy under the leadership of Lee Kuan Yew.

\section{Talent Management and Governance: Motivational Compensation}

Lee constituted his government with people of intellectual and moral superiority. Good government requires most of all leaders who put the public good unquestionably above their own personal interests.

Lee Kuan Yew leveraged the nation's human resources to build national competitiveness. Since its inception, Lee took educational reform to transform its population to its effective resource. Lee garnered the best teams' right from the start. Lee practiced a culture of meritocratic selection to retain the best talent. He emphasized education from primary level to university level. In recruiting political leaders, PAP leaders drifted away from the traditional "political leadership" ideology and resorted to tea sessions, interviews, psychological testing to sieve out the best from the academically best students. In Lee's words:

"Singapore must get some of its best in each year's crop of graduates into government. When I say best, I don't mean just academic results. His ' $O$ ' levels, 'A' levels, university degree will only tell you his powers of analysis. That is only one-third of the helicopter quality. You've then got to assess him for his sense of reality, his imagination, his quality of leadership, his dynamism. But most of all, his character and motivations, because the smarter a man is, the more harm he will do society" [3].
Now, Singapore's civil service attracts the island nation's best talents. Lee looked into the incentives that people respond to and thus Singapore's world ministers are highly paid than any other government of the world. As a visionary leader ahead of his time, Lee recognized and realized the importance of motivational factors- both intrinsic and extrinsic, and offered the civil servants highly competitive compensation and benefits plans. Lee also realized that investment in training and development of the employees to upgrade their personal and managerial skills would not only motivate the employees, but also would enhance productivity by manifold. Based on this philosophy, the government of Singapore has devised its compensation plan for government employees with exceptionally higher level of opportunities for training and development. The officers who have successfully upgraded their technical and leadership skills are also rewarded with cash payouts under the Training Incentive Scheme [9].

\section{Iv. Transparency and Rule of Law}

Lee strictly adhered to the rule of law while managing Singapore's governance issues. He eschewed the idea of democratic freedom over country's economic stability and growth. His government singlehandedly curbed corruption by proper governance staff and polices. Mr. Lee himself was incorruptible. Thus, he strived to make it contagious and keep the government corruption free. Good governance was at the core of his philosophy. Lee set example for the world leaders that with appropriate political will a country plagued with corruption can get rid of the clutches of corruption. As a result, Singapore magnetized potential investors and garnered its competitive advantage in global arena. As of 2015 , Singapore is ranked as the number one country in World Banks Doing Business Report [4]. Lee identified that to develop transparencies and rule of law in every sphere of the government initial examples must be set by the top-level government officials and political leaders, and he accomplished this particular objective extraordinarily.

\section{v. Lee's Philosophy of Meritocracy}

Singapore is considered as a successful meritocratic state. Singapore's founding father Lee Kuan Yew preferred performance in terms of prosperity, stability and security over any grand philosophical basics. He firmly believed that appraisal should be based dominantly on actual performance regardless of what levels of society a person belongs to and meritocracy was a cornerstone of his ideology. Michael Young was the first to come up with the word Meritocracy in his book "The rise of meritocracy"[5]. Lee espoused the idea to produce an elite with intellectual and moral upbringing to lead Singapore's nation building mission. In the quest of building a prosperous Singapore, Lee placed a high premium on quality leadership[6]. Lee embraced the concept of meritocracy to filter the best and brightest from 
Singapore's small pool of population and coach them to for their role as elite[7]. The meritocracy system aims to provide all qualified individuals a fair and equal chance of being successful based on their own capabilities.

The ideology and practice of meritocracy in Singapore has recently been coming under close scrutiny by political analysts as its effectiveness is questioned because of empirical evidences suggesting that the ideology could actually lead to an increased amount of influence of several non-merit factors for personal and social development [8]. Since its inception in the 1950s, the government of Singapore lead by the People's Action Party (PAP) has always been actively highlighting the advantages of meritocracy i.e. talent and hard-working attitude should be the selection factor for employment and social benefits, through all the government controlled communication and social channels including public education sector and media.

The specific geographic conditions of Singapore being a small island state with almost no natural resources has contributed heavily to support the idea that merit should be the central basis of recruitment and social benefits. Meritbased recruitment system has become the base for selection process not only for the government officials in Singapore but also the students through different stages of their academic arena starting from primary school. However, this perception leads to societal inequality because too much emphasis on merit-based selection process could undermine the level-playing field for the competitors. This is largely due to the fact there are several disadvantaged groups in a society who suffer from severe lack of resources, both financial, social and familial, which obstructs their way to get ahead in the competition to prove the merit or talent while competing with the ones from the socially or financially privileged groups.

Individual merit of people can be identified through their academic performance, however, there are few potential drawbacks if the approach is oversimplified, which has happened in case of the meritocratic culture of Singapore. First of all, statistical evidence suggests that students who enjoy access to a large amount of resources in the childhood, find it easier to attain success in meritocratic term and schools with higher tuition fees perform better that schools with lower tuition fees. Moreover, it is also difficult for students from underprivileged social class to get acceptance into the top schools as it often requires a strong social connection and financial resources for admission into such schools. Hence, there is lack of definitive fair competition among people from varying social backgrounds leading to inequality and inefficiency of the meritocratic system in practice, because of greater involvement of non-merit factors than the ones related to "merit" or "talent".

The merit-based recruitment system for public services practiced in Singapore is not what it is supposed to be in theory as well. Many of the crucial government positions are held by close relatives of the former President Lee's family including cousins, uncles, siblings, and in-laws as well. The government puts its efforts to maintain people's trust through a sophisticated job rotation system for public officials combined with harsh punishment for corruption. The meritocratic system in Singapore has also failed to provide adequate support and social benefits to groups which are historically underprivileged including nonChinese citizens, women and poor. This lack of community support and social protections have contributed to the drastic rise of inequality in the Singaporean economy, which currently has one of the highest level of Gini coefficients in the world.

Therefore, recently the effectiveness of the meritocratic culture in Singapore has raised a lot of questions and criticisms, and the new generation of constituents have already voiced their opinions and concerns to renegotiate the system through election and media.

\section{Conclusion}

Lee Kuan Yew can be considered as a quintessence of a leader that can transform a country positively. Though his stance against media, opposition is often under the thorns of criticism, his long term vision in shaping a country is considered as exemplary even by the west.

Ahead of his time, Lee realized the importance of modern human resource and talent management practices to develop and nurture exceptional leadership skills in the government officials and to create a highly skilled and motivate workforce. Lee's meritocratic philosophy brought out potential leaders for the country, but the question of equality is still at stake. Lee upheld rule of law to ensure public accountability and devised incentive to join best of country's talents in its civil service. Political leaders thriving to propel their countries can draw important lessons from this visionary thereby.

\section{References}

[1] Lee Kuan Yew, speech to school principals, Victoria Theatre, 29 August 1966, in Han et al., Lee KuanYew,pp. 393-5, p. 394.八

[2] Lee Kuan Yew, speech at a seminar on communism and democracy, 28 April 1971, in Han et al., Lee KuanYew, pp. 313-16, p. 315.

[3] Lee, speech in Parliament, cited in Han et al., Lee Kuan Yew, p. 89

[4] http://www.doingbusiness.org/ /media/giawb/doing\%20business/doc uments/profiles/country/SGP.pdf

[5] Cited in Amartya Sen, "Merit and Justice", In Meritocracy and Economic Inequality. Eds. Kenneth Arrow, Samuel Bowles, and Steven Surlauf (Princeton, New Jersey: Princeton University Press, 2000), p. 7.

[6] Michael D. Barr, and ZlatkoSkrbiš, "Constructing the Nation: Elitism and Ethnicity."Constructing Singapore: Elitism, Ethnicity and the Nation-building Project (Copenhagen: NIAS, 2008), p. 44.

[7] Diane K. Mauzy, "Leadership Succession in Singapore: The Best Laid Plans", Asian Survey 33.12 (1993): 1173.

[8] Sapari, N. E. (2013, September). Questioning Meritocracy in Singapore. 5(1), 21-28.

[9] Yong, C. (2015, March 10). Singapore Budget 2015: 2,200 lowerwage civil servants to get $\$ 60$ to $\$ 80$ pay raise in April. The Straits Times. Retrieved July 30, 2015, from http://www.straitstimes.com/singapore/singapore-budget-2015-2200lower-wage-civil-servants-to-get-60-to-80-pay-raise-in-april 
Proc. of The Fourth Intl. Conf. On Advances in Economics, Management and Social Study - EMS 2015

Copyright (C) Institute of Research Engineers and Doctors, USA .All rights reserved.

ISBN: 978-1-63248-071-2 doi: 10.15224/ 978-1-63248-071-2-32

About Author (s):

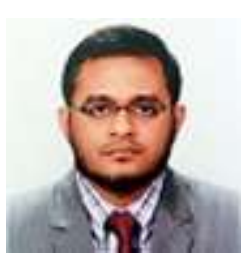

S M Saleh Reza is currently teaching at Daffodil International University. He has completed his MBA with a major in Human Resources Management from North South University, Bangladesh. $\mathrm{He}$ is also a $\mathrm{PhD}$ researcher at Bangladesh University of Professionals.

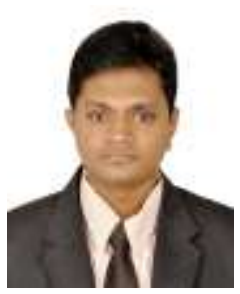

S M Sazid Raihan is currently pursuing his Masters in Business Administration, with a major in Human Resources Management, in North South University. He has obtained his Bachelors in Business Administration from North South University. His research interests are human resource management, entrepreneurship and organizational management.

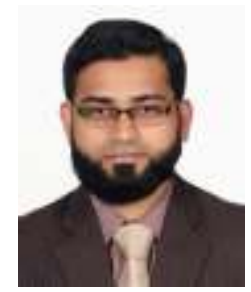

Md. Rabiul Islam Rabi has completed his Masters and Bachelors in Social Science in Economics from Department of Economics, University of Dhaka. His research interest focuses on human capital, economic growth, labor economics and moral philosophy. 